\title{
Assessment of Medical Residents and Postgraduates Students' Satisfaction of Thesis Supervision in Iran University of Medical Sciences
}

\author{
Pourbairamian. $\mathrm{G}^{1}$ \\ Sotoudeh. $\mathrm{F}^{2}$ \\ Ghasabi. M ${ }^{3}$ \\ Mansouri. M4 \\ *Sohrabi. $Z^{5}$
}

1- Ph.D., Student in Medical Education, Center for Educational Research in Medical Sciences (CERMS), Medical Education Department, Faculty of Medicine, Iran University of Medical Sciences, Tehran, Iran.

2-MSc Student in Medical

Education, Center for

Educational Research in Medical Sciences (CERMS), Medical Education Department, Faculty of Medicine, Iran University of Medical Sciences, Tehran, Iran.

3- MSc Student in Medical

Education, Center for

Educational Research in Medical Sciences(CERMS), Medical

Education Department, Faculty of Medicine, Iran University of Medical Sciences, Tehran, Iran.

4- MSc Student in Medical Education Center for Educational Research in Medical Sciences (CERMS), Medical Education Department, Medical Education Department, Faculty of Medicine, Iran University of Medical Sciences, Iran, Tehran.

5- ( ${ }^{*}$ Corresponding Author) Ph.D., Medical Education, Associate Professor, Center for Educational Research in Medical Sciences(CERMS), Associated Professor, Medical Education Department, Faculty of Medicine, Iran University of Medical Sciences, Tehran, Iran. Email: sohrabi.z@iums.ac.ir

\section{Abstracts}

Intruduction: The thesis is one of the most important parts of the teaching of medical students and postgraduate student's education. Thesis supervision is creating a learning agreement between students and supervisors and clarifying the roles of students and supervisors.

Objective: The success of students in acquiring research experience is one of the main goals of the thesis, and students' satisfaction assessment is one of the most important challenges of that. So, this study was conducted to determine the satisfaction of postgraduate students and Residentss of Iran University of Medical Sciences from directing and supervising theses.

Materials and Methods: In this descriptive-cross sectional study, 250 Medical Residents and Postgraduates Students from different steps of thesis conducting were questioned. Data ghathering instrument was the PREQ standard questionaire that it's validity and relability was confirmed. The data was analysed with use of SPSS21. The questionnaire examined six domains of the thesis. Kruskal-Wallis test for data analysis and Mann-Whitney test for comparing of means differences was used.

Results: In this study, $56.5 \%$ of postgraduates and $63.8 \%$ of medical residents expressed their satisfaction from the thesis supervision. There was no significant difference between the mean satisfaction scores in all domains in both groups. Supervisor professor, development of research skills, and thesis test earneed the most satisfaction score; and providing conditions and fields of thinking growth, infrastructure and facilities domains acquired the lowest satisfaction score.

Discussion and Conclusion: Findings showed the satisfaction level of both groups was relatively desirable. As regard that Significance difference was observed between proposal confirming, providing conditions and fields of thinking growth, development of research skills and clarifying of criteria, and goals with students' satisfaction, attention is needed to increase the skills and enhance the ability of students to conduct independent research, in the early years of postgraduate education.

Keywords: Postgraduate Students, Resident, Satisfaction, Thesis Supervision. 


\title{
مقايسه رضايتمندى دستياران يزشكى و دانشجويان تحصيلات تكميلى دانشكاه علوم بزشكى

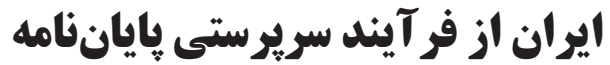

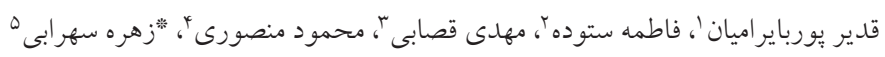

جكيده

مقدمه: پاياننامه از مهمترين بخشهاى آموزش دانشجويان يزشكى و تحصيلات تكميلى مىباشد. سريرستى پايانامها،

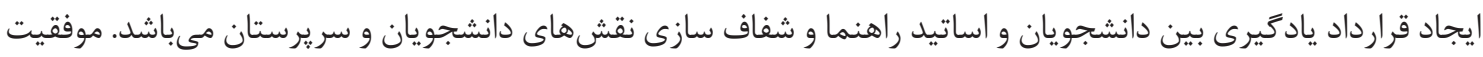

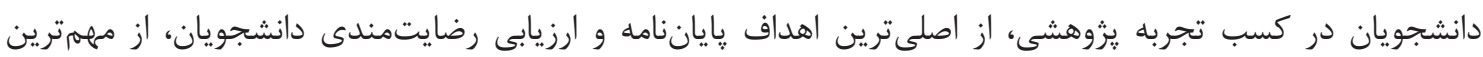
جالشهاى آن مىباشد. هدف: اين يزوهش با هدف تعيين رضايتمندى دستياران و دانشجويان تحصيلات تكميلى دانشخاه علوم يزشكى ايران از نحوه هدايت و سريرستى پايان نامهها انجام گرفت.

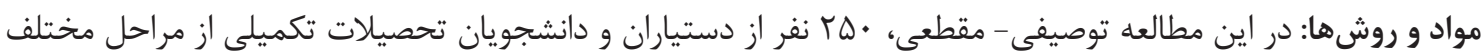

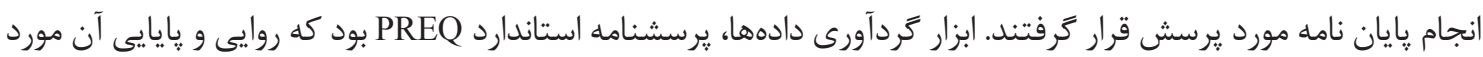

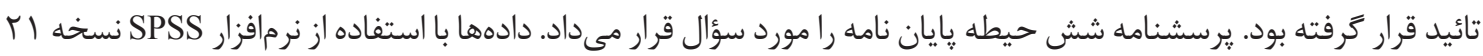

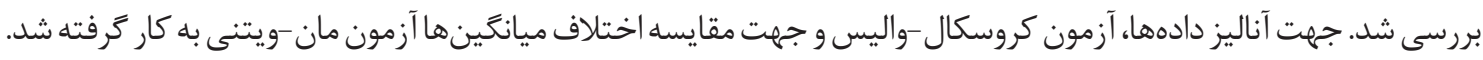

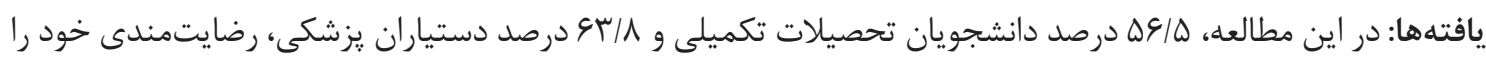

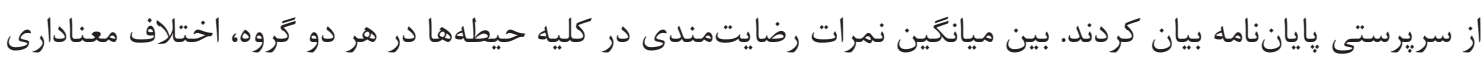

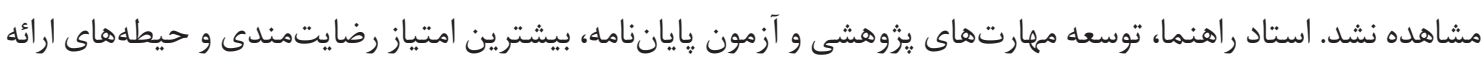
شرايط و زمينههاى رشد فكرى و زير ساختها و امكانات، كمترين ميزان را به خود اختصاص داص دادند.

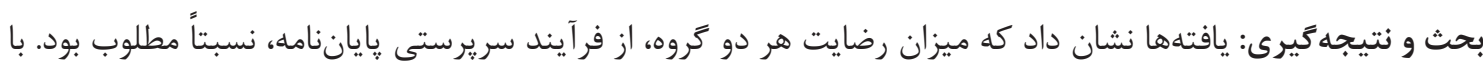

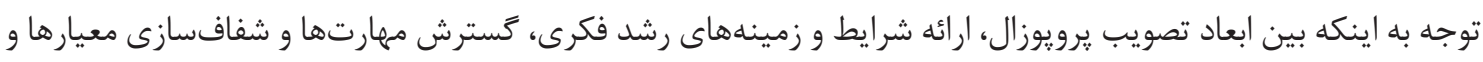

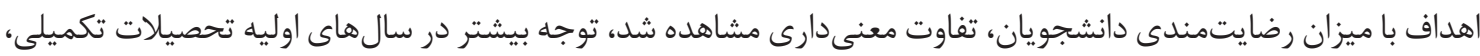
به افزايش مهارتها و ارتقاء توانايى دانشجويان در انجام تحقيقات مستقل، ضرورى به نظر مىرسد.

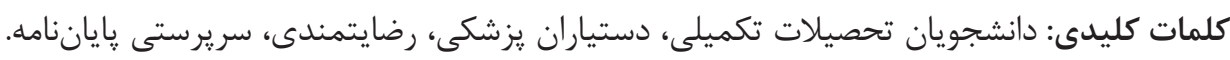

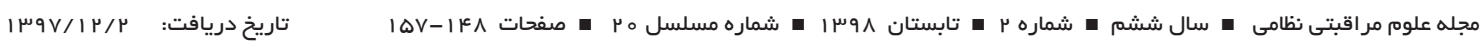
تاريخ يذيرش: ت تاريخ دريافت: تاريخ انتشار: : تاريخ بذرش:

نمود خود را در واحد پاياننامه نمايان ساخته و دانشجويان با

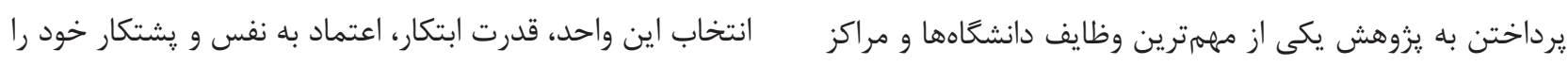

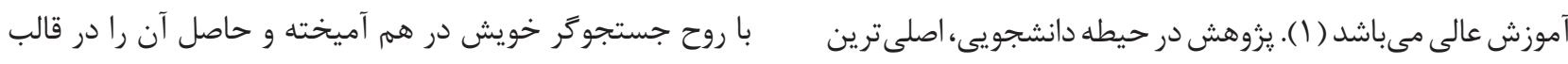

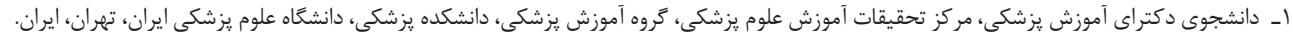

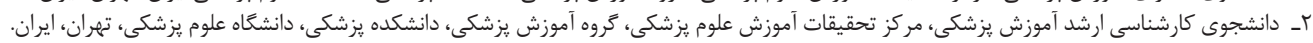

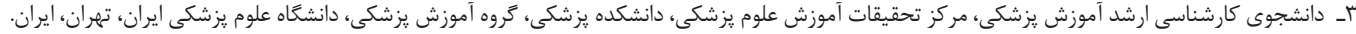

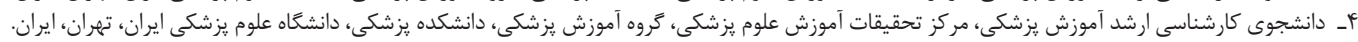

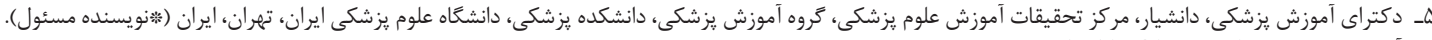
آدرس الكترونيك: sohrabi.z@iums.ac.ir 
دسترسى به استاد اختصاص داده شده بود (f أ، ه|).

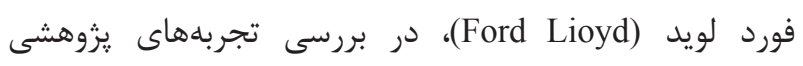

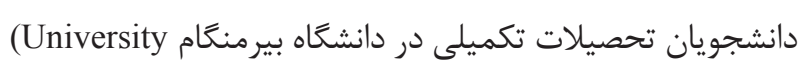

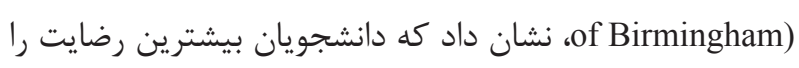

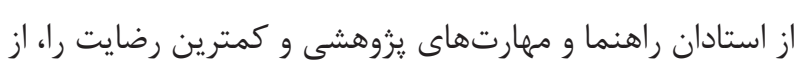

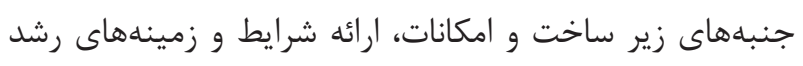

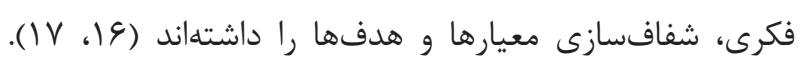

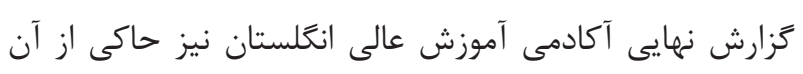

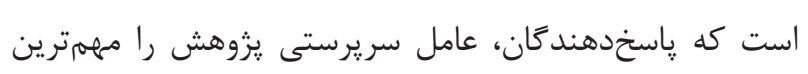
عامل در موفقيت برنامههاى يزوهشى خود عنوان كردماند (1) (1).

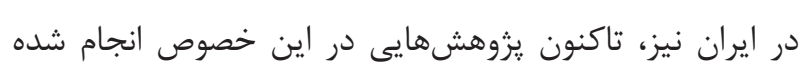

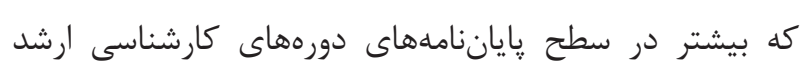

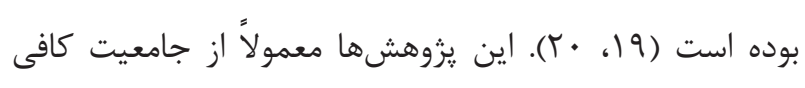
برخوردار نبوده و داراى نقاط ضعف اساسى بودهاند؛ از جمله

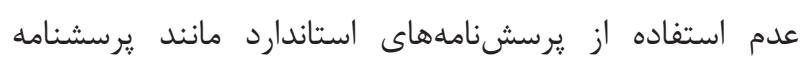
Postgraduate Research Experience Questionnaire (PREQ) است (آY-YY). براى نمونه اسماعيل و همكاران در بررسى خود با عنوان، بهبود و توسعه يزوهشى تحصيلات تكميلى و استادان راهنما، نشان دادند كه دانشجويان، زير ساختها و و امكانات

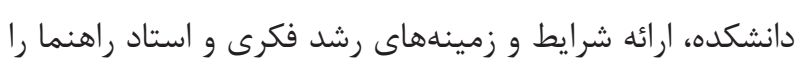

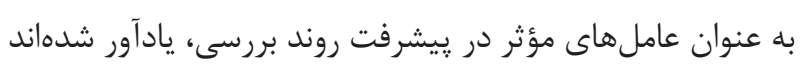

لذا، آشنايى با نحوه سريرستى پاياننامهها و مقايسه ميزان

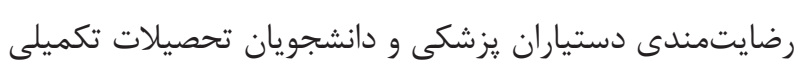

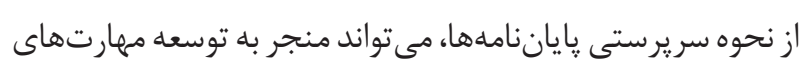

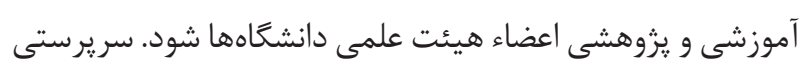

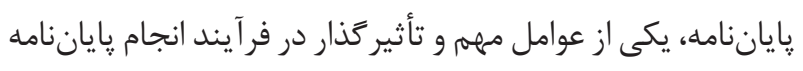
مىباشد كه ارزيابى نظرات دانشجويان و شناسايى موارد مربوط

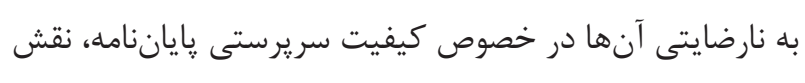

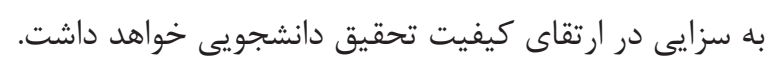
از سويى ديكر از آنجا كه در حوزه بهداشت و درمان، فعاليتها به صورت كروهى و تيمى انجام مىشود، بنابراين، يك ارتباط

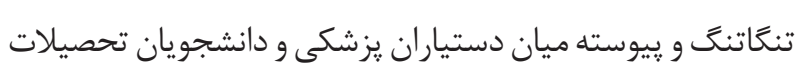
تكميلى وجود دارد كه نشاندهنده اهميت رشتههاى تحصيلات
ְاياننامه ارائه مى دهند (T). اين اثر در واقع، عصاره و جكيده

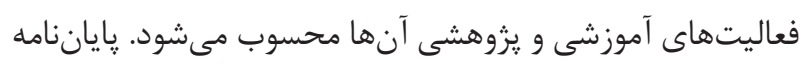

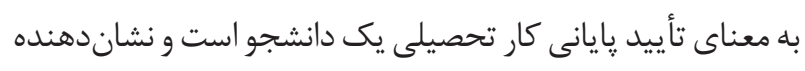
فعاليتهاى منسجم او به حساب مى آيد كه با راهنمايى استاد

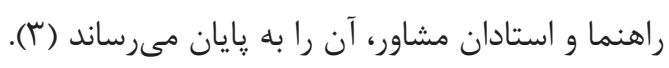

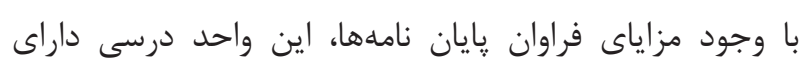

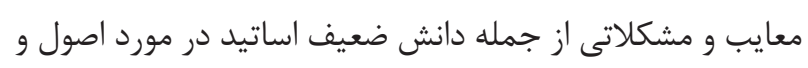
روشهاى تحقيق، فقدان وقت كافى براى راهنمايى دانشجويان،

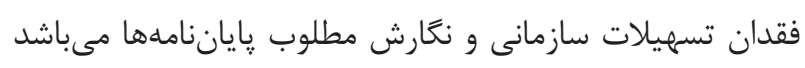

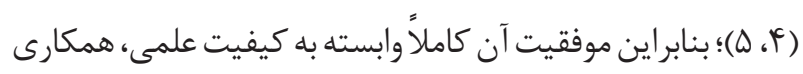

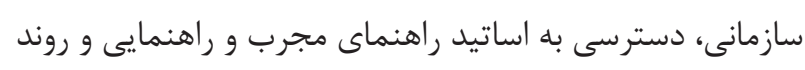

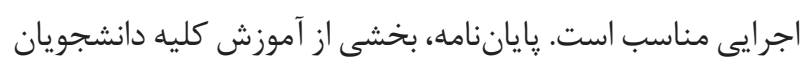

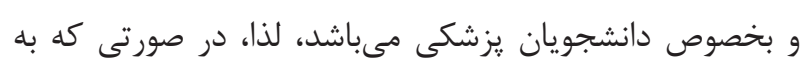

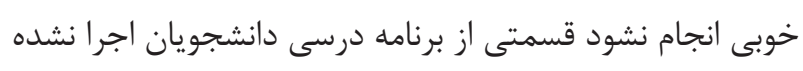

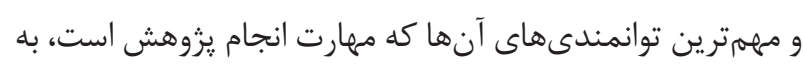

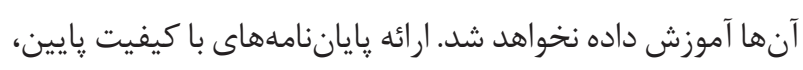

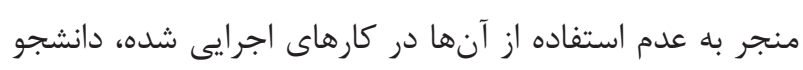

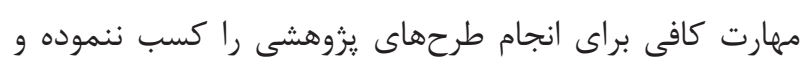

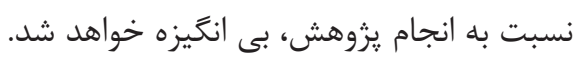

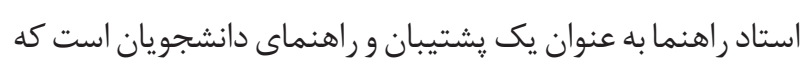

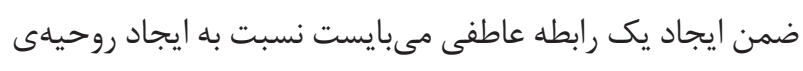

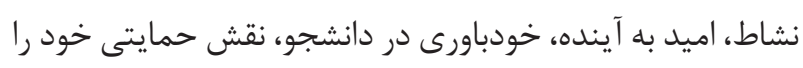

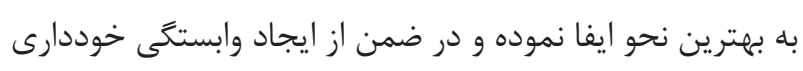

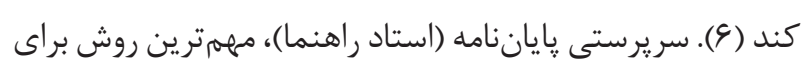
ايجاد يك قرارداد يادكيرى بين دانشجويان و اساتيد راهنما، ايجاد

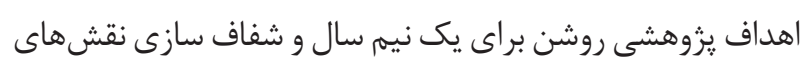

دانشجويان و سريرستان مىباشد (V) يزوهش هايى در ارتباط با ين موضوع در دانشكاههاى عربستان، نرور،

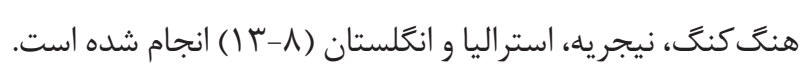
براى مثال در تحقيقات انجام شده توسط مك آليس (McAlees)،

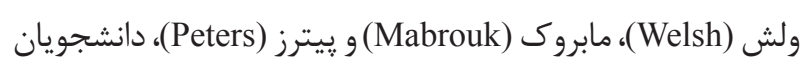

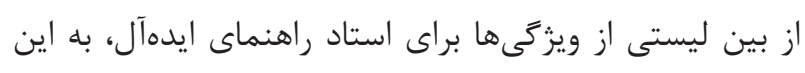

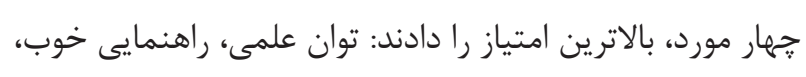

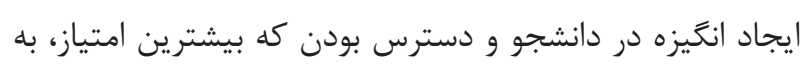


نموده است. بهزادى عامل ها و متغيرهايى كه متناسب با هنجارها

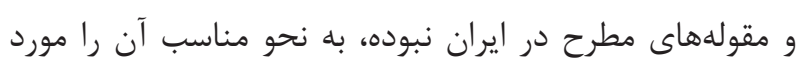

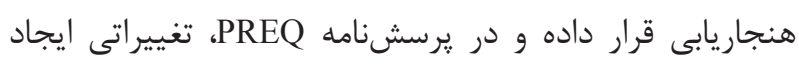

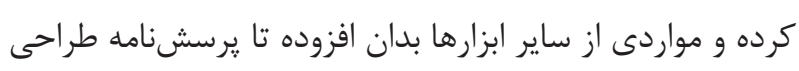

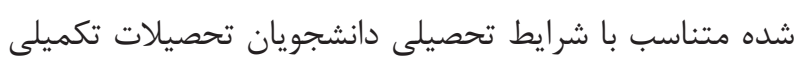

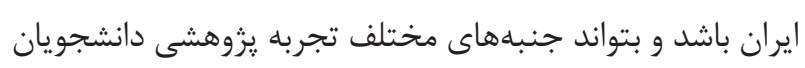

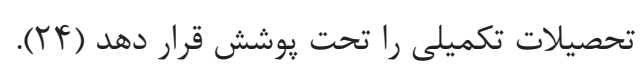

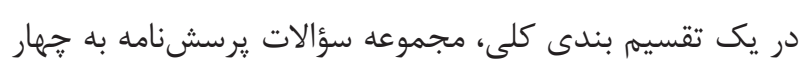

بخش تقسيم مىشود:

1. اطلاعات جمعيت شناختى پِاسخ دهند مان كه شامل: جنس، مقطع تحصيلى، رشته تحصيلى، سابقه نكارش مقاله يا خاب

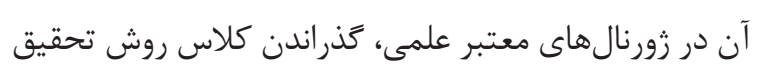
و ارائه مقاله علمى در سمينارهاى علمى است. r. اطلاعات كلى ييرامون پايان نامه دانشجويان

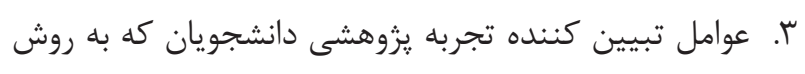

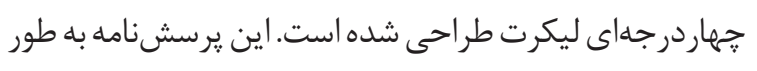

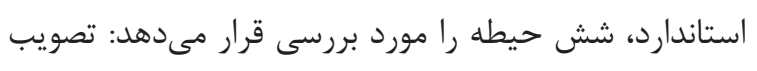
طرح مقدماتى، سريرستى پاياننامه، زيرساختها و وامكانات

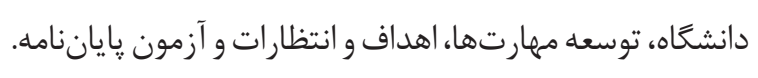

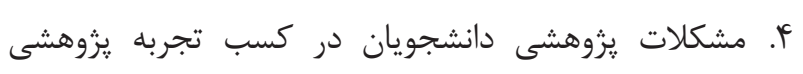
مناسب

در تمامى متغيرهاى يرسشنامه از مقياس ليكرت استفاده شده است.

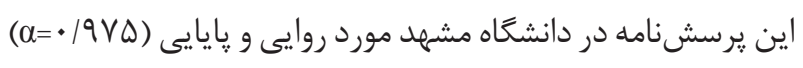

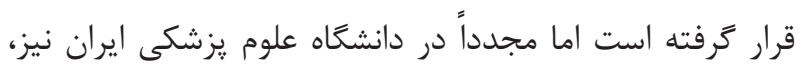
روايى و يايايى :يرسشنامه تعيين گرديد.

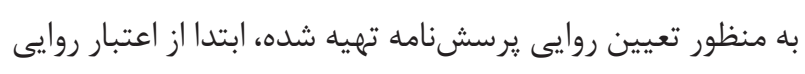

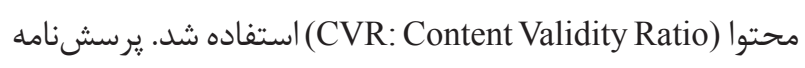
بين r ا نفر از اعضاى هيئت علمى كروه آموزش يزشكى و همجرنين تعدادى از اعضاى هيئت علمى گروه بهداشت و يزشكى إنى اجتماعى

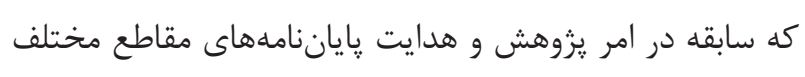

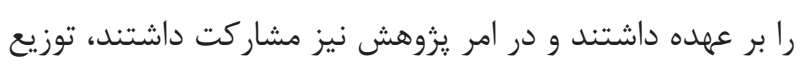

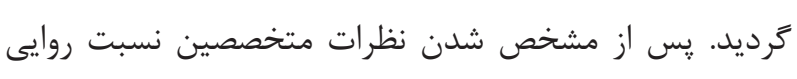

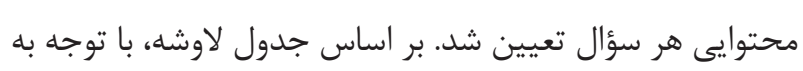

تكميلى در دانشعاههاى علوم يزشكى مىباشد. دليل مقايسه

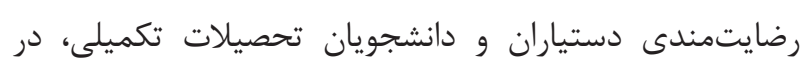
حقيقت بررسى ميزان تأثير سطح تحصيلات با ميزان رضايتمندى دان داني

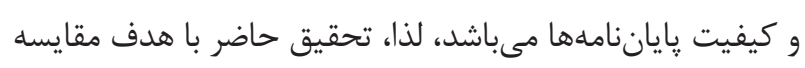
رضايتمندى دستياران و دانشجويان تحصيلات تكميلى دانشخاه

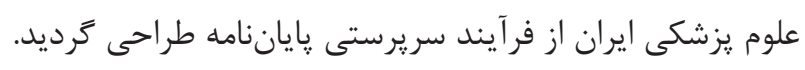

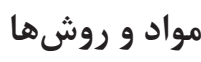

يزوهش حاضر يك يزوهش توصيفى - مقايسهاى است. جامعه

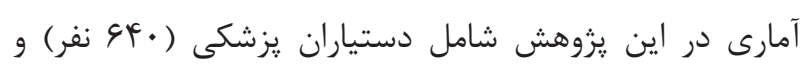
دانشجويان تحصيلات تكميلى در دانشكدهاى داى دانشخاه علوم

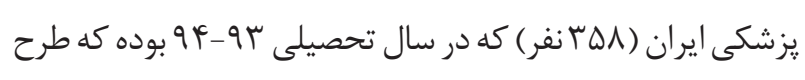

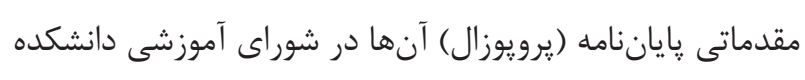
به تصويب رسيده و در حال انجام امور مربوط به باياننامه خود إنانه

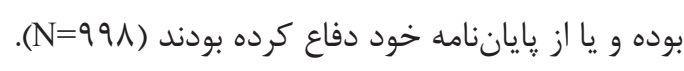

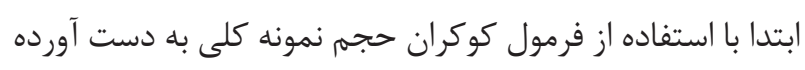

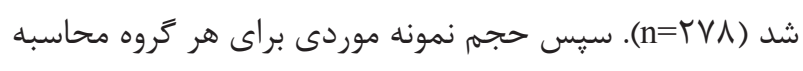

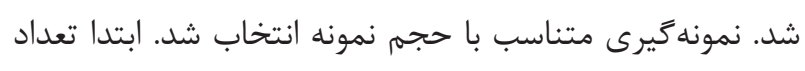

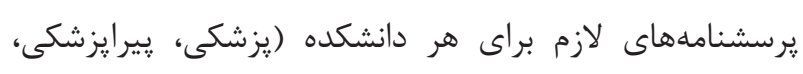

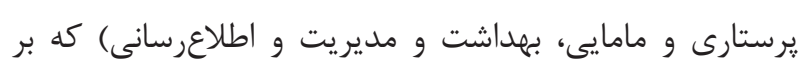

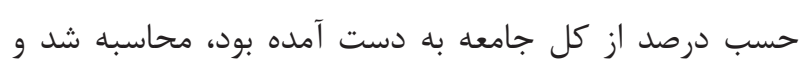

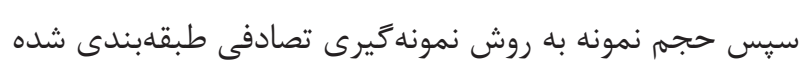

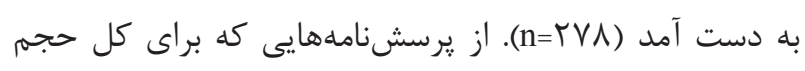

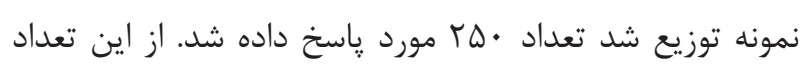
IV9 نفر دستياران، IV كارشناسى ارشد بودند.

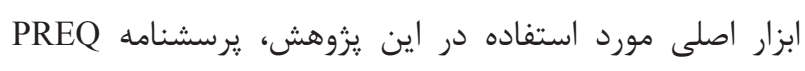
(Postgraduate Research Experience Questionnaire) كه توسط انجمن فارغ التحصيلان استراليا و انجمن تحقيقات

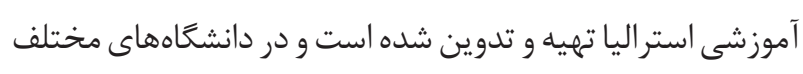

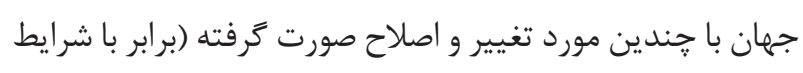
خودشان)، براى سنجش سريرستى پاياننامه مورد استفاده قرار

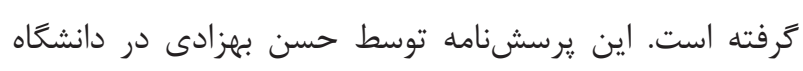
فردوسى مشهد هنجارسازى شده و در پايان نامه از آن استفاده 


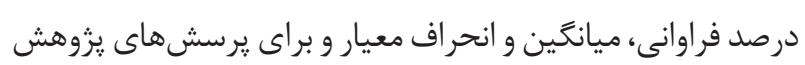

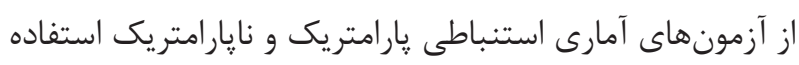

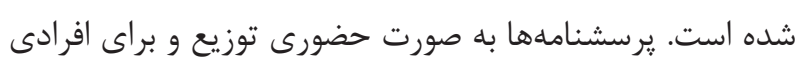

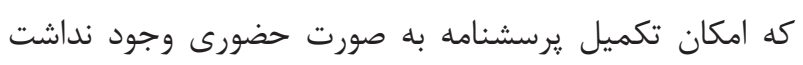

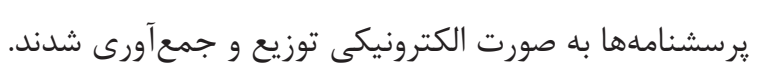

\section{بافتهها}

با توجه به اهداف يزوهش، يافتههاى زير به دست آمد:

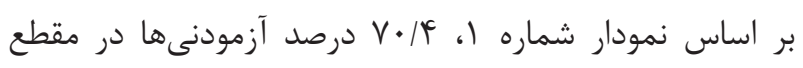
دستياران و بقيه در مقطع كارشناسى ارشد و دكترا بودند. همجنين همان گونه كه در جدول شماره 1 مشاهده مىشود،

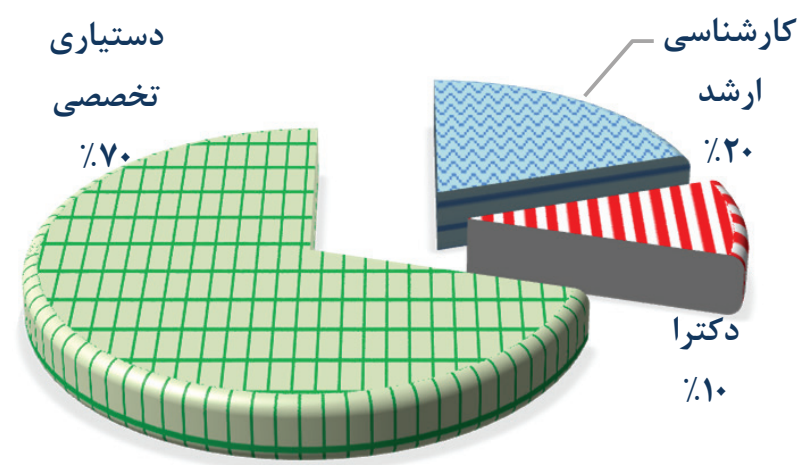

نمودار ا - توزيع فراوانى آزمودنىها به تفكيك مقطع تحصيلى

جدول ا- توزيع آزمودنى ها بر اساس انتخاب موضوع يايان نامه

\begin{tabular}{|c|c|c|c|}
\hline درصد & تعداد & جَّكونَى انتخاب & \\
\hline$r T / F$ & TY & خودم & \multirow{6}{*}{ تحصيلات تكميلى } \\
\hline$\varphi / 1$ & r & كروه آموزشى & \\
\hline$r \Lambda / F$ & TI & استاد راهنما & \\
\hline$T / V$ & $r$ & افراد ديخرى & \\
\hline$M T / F$ & TF & بين من و استاد راهنما & \\
\hline $1 \cdots$ & $V F$ & جمع & \\
\hline $\mid 1 / \Lambda$ & TG & خودم & \multirow{6}{*}{ دستياران يزشكى } \\
\hline $1 \pi / 1$ & r & عروه آموزشى & \\
\hline$\Delta V / \mathcal{F}$ & $1 \cdot 1$ & استاد راهنما & \\
\hline r & $\checkmark$ & افراد ديخرى & \\
\hline $1 \cdot 11$ & 19 & بين من و استاد راهنما & \\
\hline $1 \cdots$ & IVE & جمع & \\
\hline
\end{tabular}

اينكه rا نفر متخصص نظرات خود را راجع به يرسشنامه اعلام كردند، شاخص قضاوت در مورد هر سؤال وها• در نظر زرفته شد. با توجه به امتياز نتايج به دست آمده از اعتبار محتوا، نشان

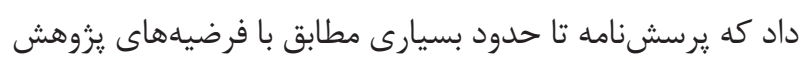
بوده است و در برخى موارد نقطه نظرات اساتيد مورد توجه قرار گرفته و اصلاحات لازم صورت گرفت. با توجه به نظر اساتيد مشاور و راهنما و همجنين نظرات متخصصين در خصوص روايى صورى،

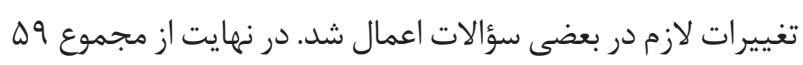
سؤال يرسشنامه، س سؤال حذف و rا سؤال يرسشنامه، اصلاح

و يذيرفته شدند (تعداد كل سؤالات يرسشنامه وه مورد شد). شاخص روايى محتوايى (CVI: Content Validity Index) نشان دهنده جامعيت قضاوتهاى مربوط به روايى يا قابليت اجراى مدل آزمون يا ابزار نهايى مىباشد. هر جه مقدار روايى محتوايى نهايى

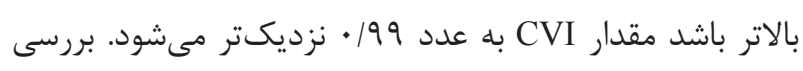
CVI CVI بر اساس نتايج حاصل، اساتيد اعلام كردند كه اكثر سؤالات مورد قبول دارند. سؤالاتى كه CVI كمتر از حد انتظار ( •/V) داشتند اصلاح و سيس يذيرش شدند. به اين ترتيب در اين يزوهش

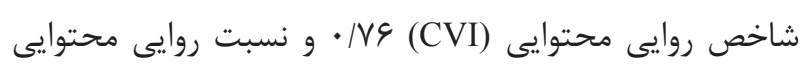
/ DV (CVR) تعيين يايايى، ضريب آلفاى كرونباخ مورد استفاده قرار گرفت به اين ترتيب كه يرسشنامه توسط ها نفر از دانشجويان تحصيلات تكميلى كه به روش تصادفى انتخاب شده بودند تكميل گرديد. ضريب آلفاى كرونباخ 9V/ • به دست آمد. در اين تحقيق براى سنجش رضايتمندى از سريرستى پاياننامه

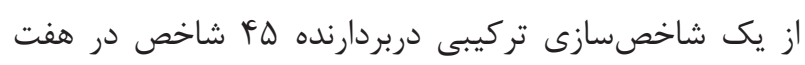
حيطه، فرآيند تصويب زيرويوزال (جهار شاخص)، استاد راهنما (هفت شاخص)، زير ساخت و امكانات دانشعاه (هشت شاخص)،

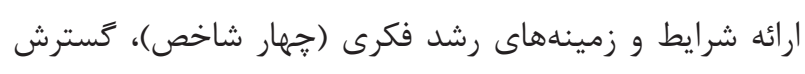
مهارتهاى يروهشى (يازده شاخص)، شفافسازى معيارها و اهداف (جهار شاخص) و آزمون يايان نامه (هفت شاخص) استفاده شد.

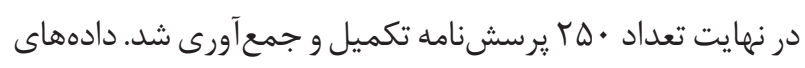

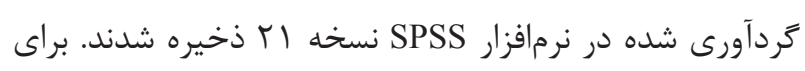
تجزيه و تحليل دادهاى اين يزوهش، از آمار توصيفى فراوانى، 
عوامل مشكلات ثروهش با سطح رضايتمندى، ارتباط معكوس

$$
\text { و معنى دار وجود دارد. }
$$

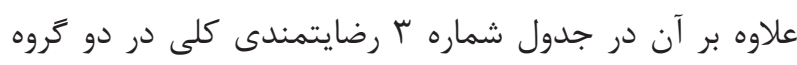

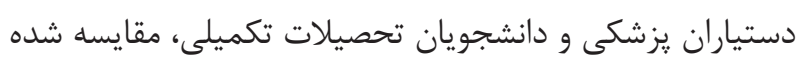

$$
\text { است. }
$$

\section{بحث و نتيجه}

يافتهها نشان داد كه رضايتمندى كلى دانشجويان تحصيلات

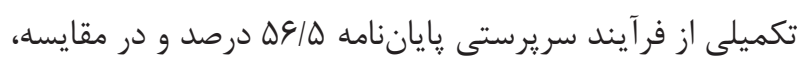

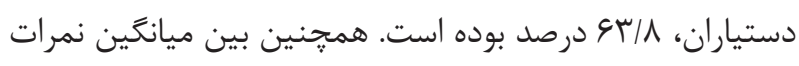

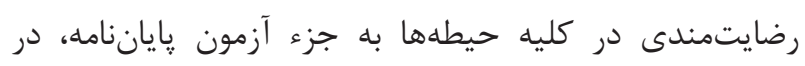

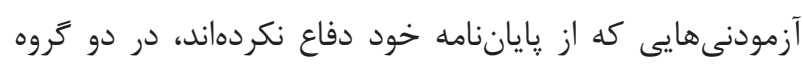

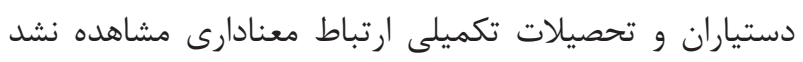

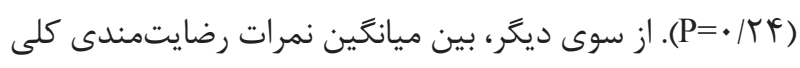

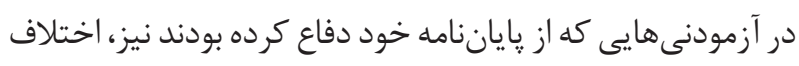

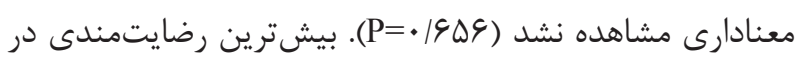

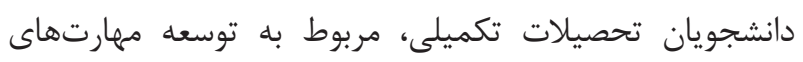

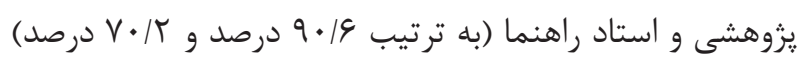
بوده است، در حالى كه دستياران به ترتيب از استاد راهنما
هV درصد از دستياران يزشكى، انتخاب موضوع پايان نامههايشان

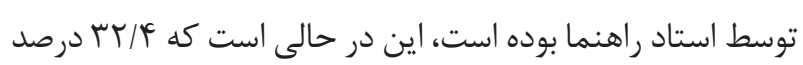
از دانشجويان تحصيلات تكميلى، موضوع پايان نامه را خود انتخاب

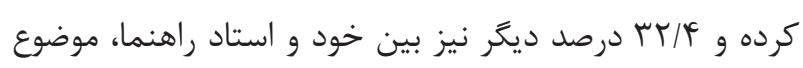
را انتخاب كردهاند.

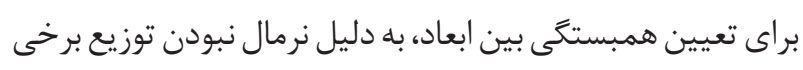

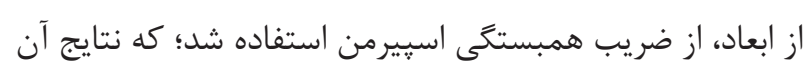
در جدول شماره r آورده شده است.

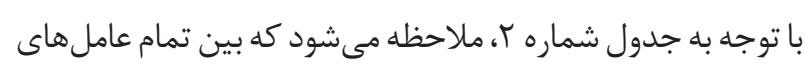

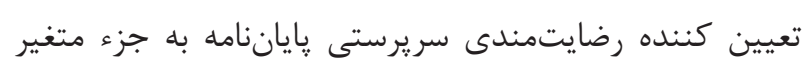

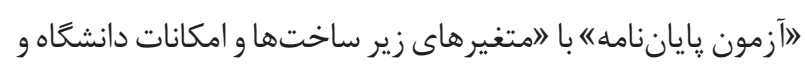

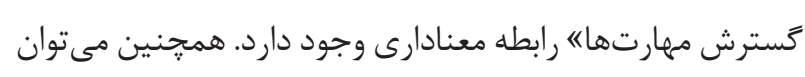

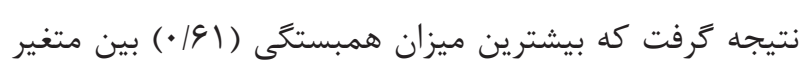

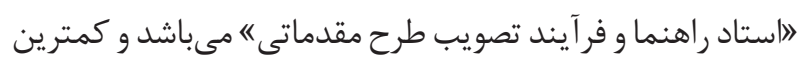

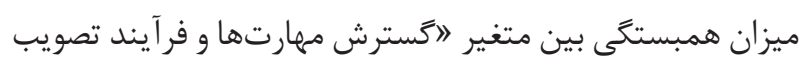
طرح مقدماتى" مىباشد. از سوى ديگر بين تمامى عاملها به هيه

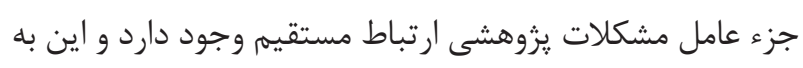

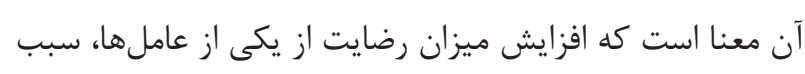

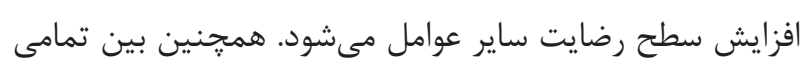

\begin{tabular}{|c|c|c|c|c|c|c|c|c|}
\hline ي & ع & شفاف سازى & مهارت ها & زرمينه رهاى رائه شر و ركرى & زيرساختها و امكانات & استاد & طر طرح مقدمآيند تصويب & \\
\hline & & & & & & & & فقدآيند تصويب طرح \\
\hline & & & & & & & .191 & استاد راهنما \\
\hline & & & & & & $\cdot / T V$ &.$|4|$ & زايرساختها و انشكاه \\
\hline & & & & & .109 & .148 & $\cdot / 0$ & زمينههاى رشد فكرى شرايط و \\
\hline & & & & $\cdot / 4$ & ع & $\cdot / r \Delta$ & $\cdot \pi$ & كسترش مهارتها \\
\hline & & & $\cdot / 4$ & $\cdot / \Delta \Delta$ & - MF & . &.$/ 49$ & شفافسازى معيارها و \\
\hline & & .149 & r & $\cdot \mid \Delta T$ &.$/ 14$ & $\cdot 19$ &.$/ 49$ & دفاع پاياننامه \\
\hline &.$-|4|$ &.$- / 4 \pi$ & $-\cdot|r|$ & $-\cdot|r|$ &.$- / T T$ &.$- / 4 \Delta$ & $-\cdot / r$ & آزمون پاياننامه \\
\hline
\end{tabular}

جدول r- نتايج آزمون همبستكى بين ابعاد 
جدول ب - رضايتمندى كلى از فر آيند سريرستى پاياننامه

\begin{tabular}{|c|c|c|c|c|c|c|c|c|}
\hline \multicolumn{4}{|c|}{$\begin{array}{c}\text { دستياران تخصصى (تعداد آزمودنى ها } \\
\text { (n=lV }\end{array}$} & \multicolumn{4}{|c|}{$\begin{array}{c}\text { تحصيلات تكميلى (تعداد آزمودنى ها } \\
\text { (n=VF }\end{array}$} & \\
\hline \multicolumn{2}{|c|}{ مخالف } & \multicolumn{2}{|c|}{ 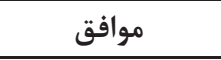 } & \multicolumn{2}{|c|}{ 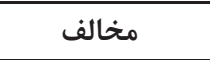 } & \multicolumn{2}{|c|}{ 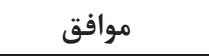 } & \\
\hline تعداد & درصد & تعداد & 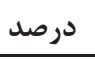 & تعداد & درصد & تعداد & درصد & \\
\hline$\Delta 1$ & $r q$ & $1 T \Delta$ & VI/I & $r \Delta$ & EV/r & rq & $\Delta T / V$ & 1 -ميزان رضايتمندى كلى از بعد تصويب طرح \\
\hline Tr & $10 / 9$ & $\mid F \lambda$ & $\Lambda F / 1$ & Tr & $r q / \Lambda$ & $\Delta T$ & $V \cdot / r$ & r- ميزان رضايتمندى كلى از بعد استاد راهنما؟ \\
\hline $1 \cdots$ & $\Delta \varepsilon / q$ & Ve & FT/T & pq & $\Delta \Lambda / 1$ & rI & $41 / 9$ & بـ مانشعاه؟ \\
\hline$\Lambda$. & $f \Delta /{ }^{c}$ & 99 & $\Delta F / Q$ & $\Delta \mu$ & $V I / s$ & TI & $r \Lambda / F$ & ر ر - ميزان رضايتمندى كلى از بعد شرايط و زمينه هاى \\
\hline$V \cdot$ & rq/v & 1.9 & $q \cdot / r$ & $\mathrm{~V}$ & $9 / 0$ & $9 V$ & $9 \cdot 19$ & ه- ميزان رضايتمندى كلى از بعد گسترش مهارتها؟ \\
\hline$\Delta \varphi$ & TI/A & 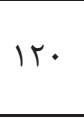 & GN/T & Mr & is & f. & $\Delta F$ & واهد ميزان رضايتمندى كلى از بعد شفافسازى معيارها و \\
\hline$\varepsilon$ & $19 / \pi$ & $r \Delta$ & $\Lambda \cdot / V$ & 9 & $r \omega / r$ & 11 & sY/V & V- ميزان رضايتمندى كلى از بعد آزمون ياياننامه؟ \\
\hline$r 90$ & r & 999 & Gr/A & $r \cdot 1$ & FT/D & T\&I & $\Delta \varepsilon / \Delta$ & رضايتمندى كلى \\
\hline
\end{tabular}

نارسايىهايى رو به رو بودهاند. ولى در نحاه كلى مىتوان دريافت كه دستياران در مقايسه با دانشجويان تحصيلات تكميلى در كليه

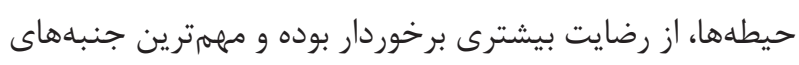

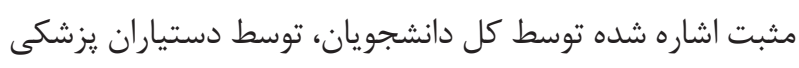

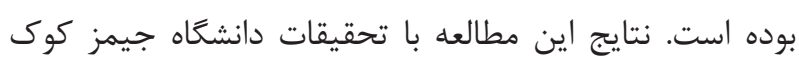

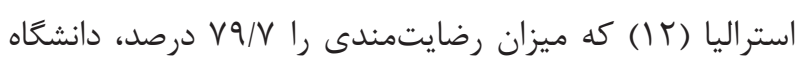

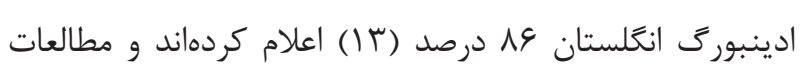
ياركر (U⿴囗十) هم خوانى دارد.

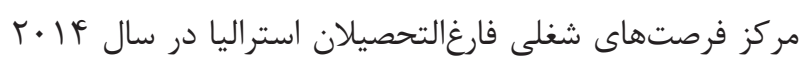

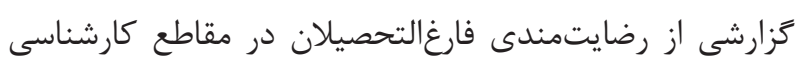

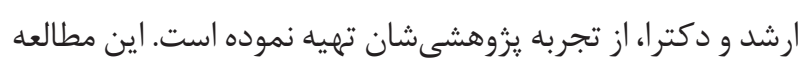

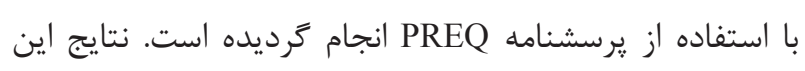

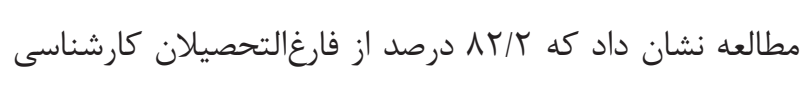

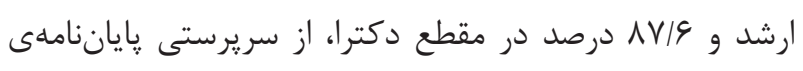

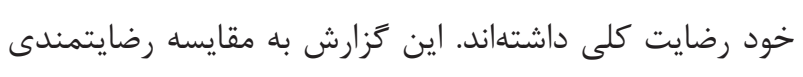

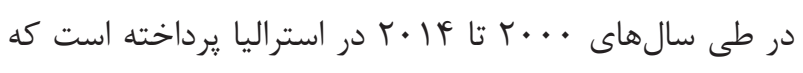
نتايج آن نشان داده كه ميزان رضايتمندى در طى اين سالها

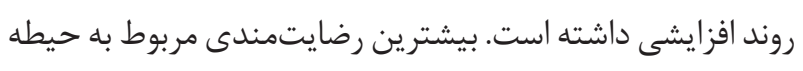

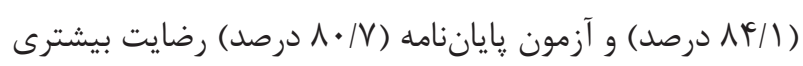

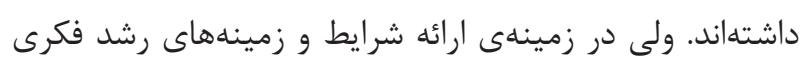

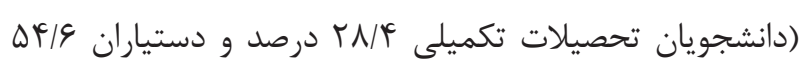
درصد) و زيرساختها و امكانات دانشعاه (دانشجويان تحصيلات

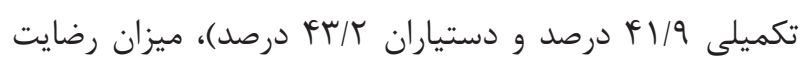
دانشآموختكان در حد متوسط و يايين بود. در زمينهى فرآيند

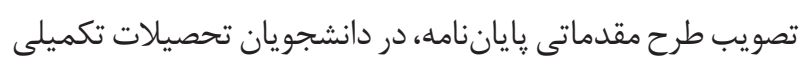

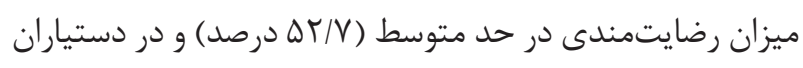

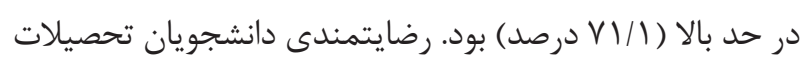
تكميلى از شفافسازى هدف ها و معيارها، وله درصد و و دستياران

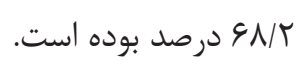
به اين ترتيب به نظر مىرسد كه دانشكاه علوم يزشكى ايران

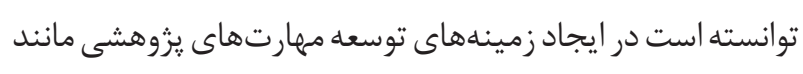

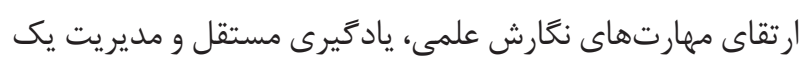

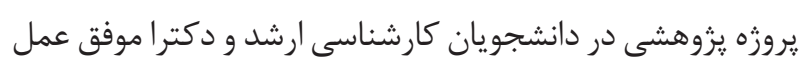

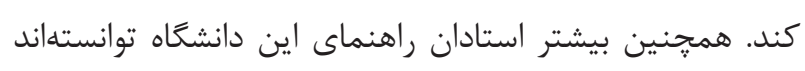
رضايت دانش آموختكان را فراهم آورند، ولى در حيطه زير ساختها رانها

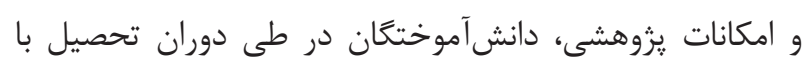


متغيرهاى جمعيت شناختى با ميزان رضايتمندى، از آزمونهاى

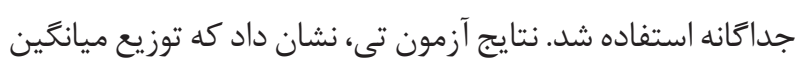

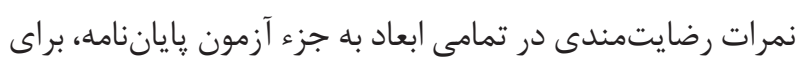

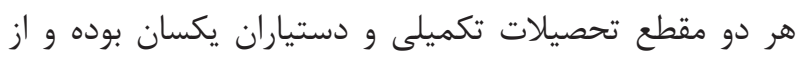

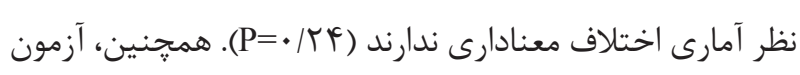

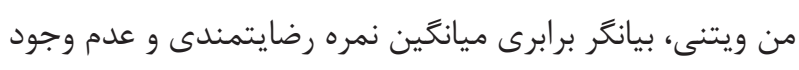

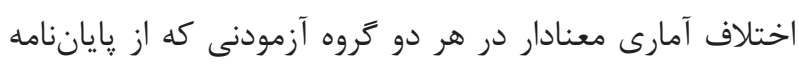

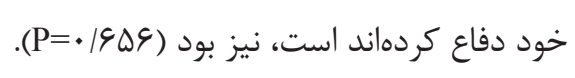

به منظور تعيين ارتباط حيطهها با نمرات رضايتمندى كل درد درد

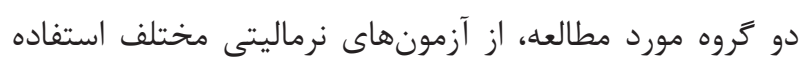

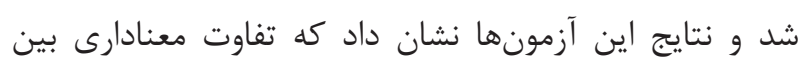

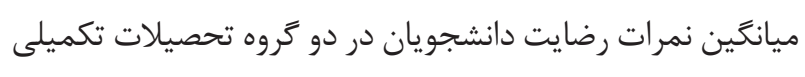

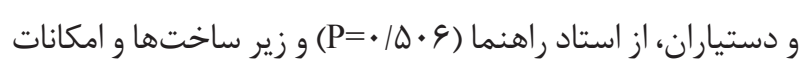

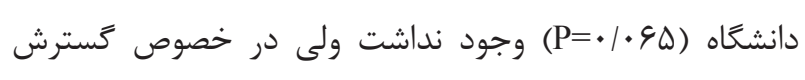

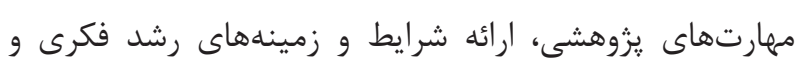

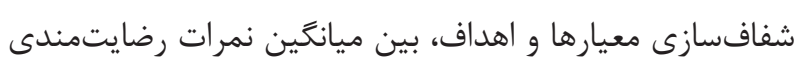

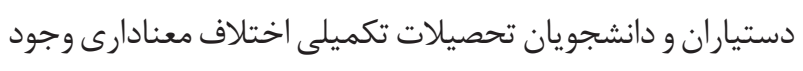

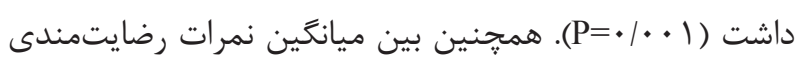

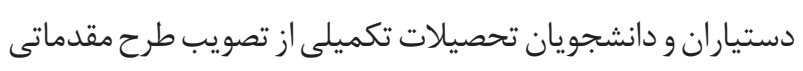

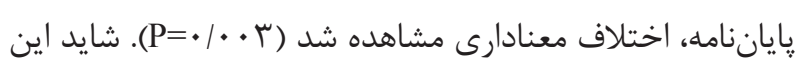
اختلاف را بتوان ناشى از اين مسئله دانست كه در اكثر موارد

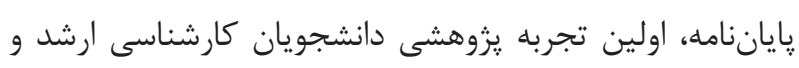

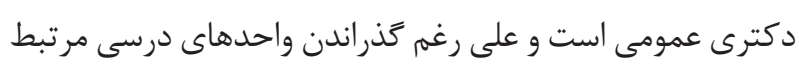

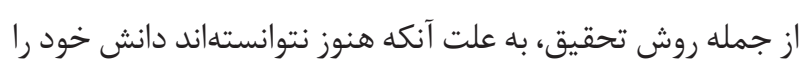

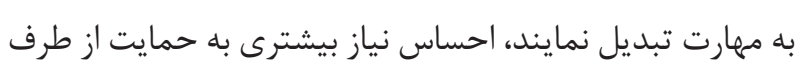

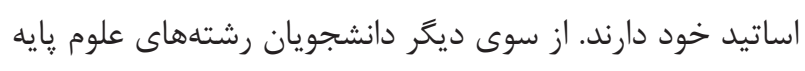

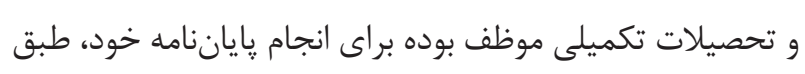

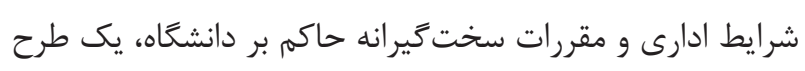

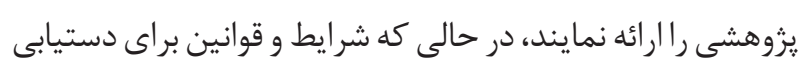

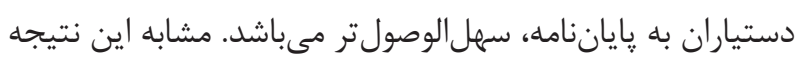

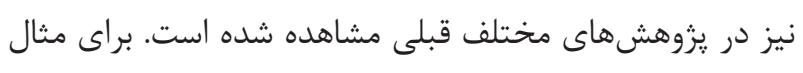
بررسى انجمن تحصيلات تكميلى امريكا نشان داد كه بسيارى از

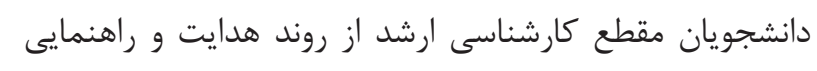
رساله خود توسط اساتيد راهنما و مشاور رضايت نداشتند (Y^).
كسترش مهارتها (V/V د درصد)، شفافسازى معيارها و اهداف (

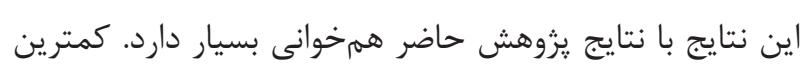

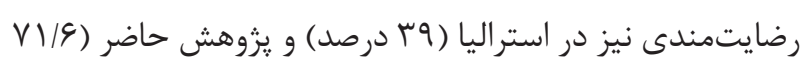

درصد)، در حيطه زمينههاى رشد فكرى مشاهده شده است.

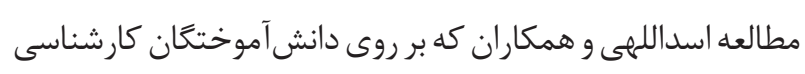
ارشد دانشكده كشاورزى دانشعاه زنجان صورت كرفت، بيانكر

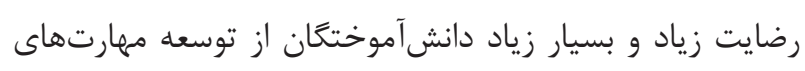

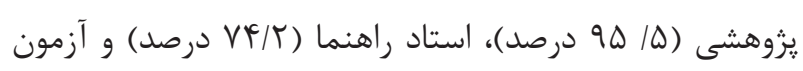

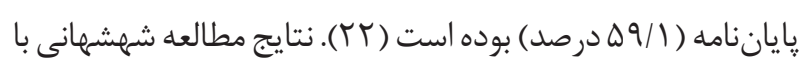
عنوان رضايتمندى دانشجويان تحصيلات تكميلى از نحوه هدايت

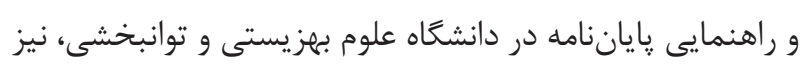

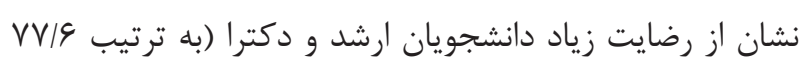

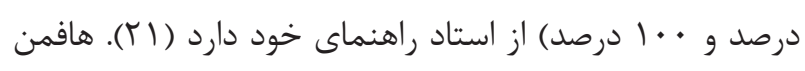
و همكارش در مطالعهاى كه در دانمارك انجام دادند، ميزان

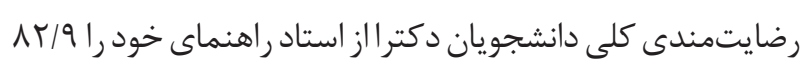

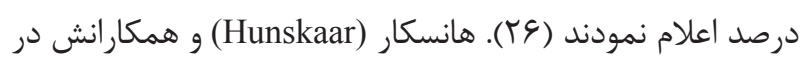

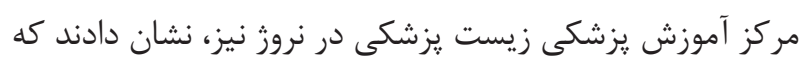

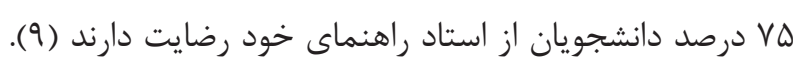

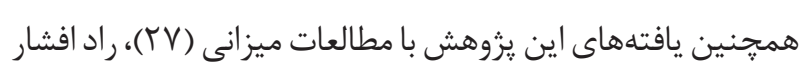

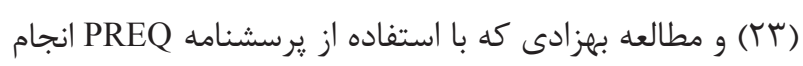

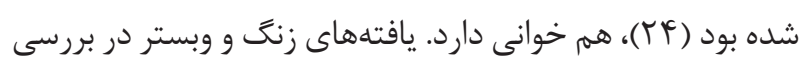
تجربههاى يزوهشى دانشجويان تحصيلات تكميلى دانشخاه هنگ

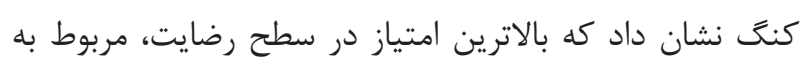

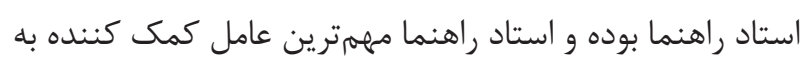
ايجاد درك مثبت دانشجويان از تجربهى يزوهشى به شمار مى آيد.

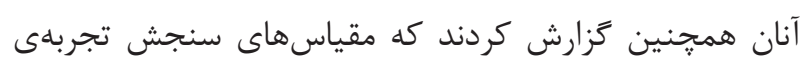
يروهشى دانشجويان شامل سريرستى پاياننامه، زيرساختهان،

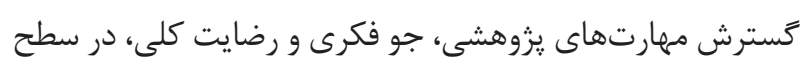
يك درصد، رابطه معنادارى با هم دارند.

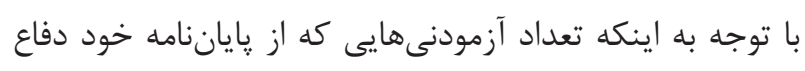

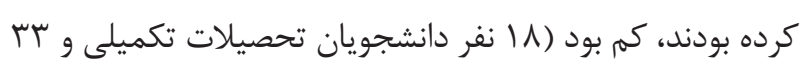

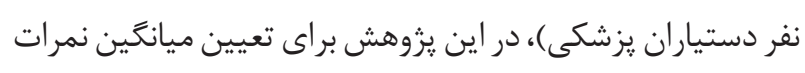

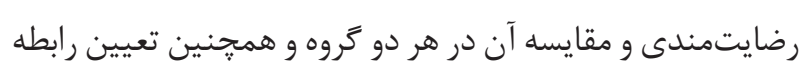


و دستياران، تفاوت معنى دارى مشاهده شد، به نظر مىرسد بهتر است در سال هاى اوليه تحصيلات تكميلى، به افزايش مهارتهاى

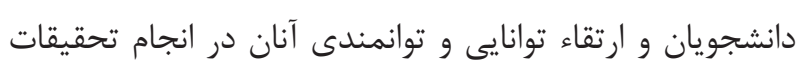

$$
\text { مستقل، توجه بيشترى شود. }
$$

با توجه به نتايج تحقيق، به منظور افزايش ميزان رضايتمندى

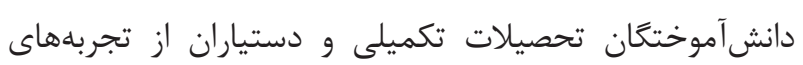
يزوهشى، ييشنهاد مى شود: مقررات، ضوابط و معيارهاى ادارى

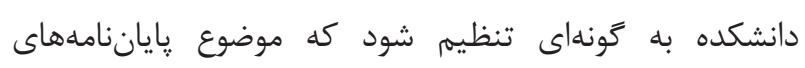

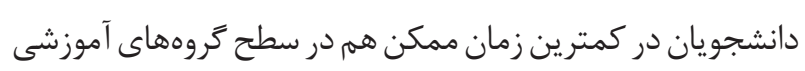
و هم دانشكده، مورد بررسى و تائيد قرار گيرد. استادان راهنما،

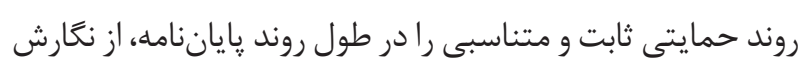

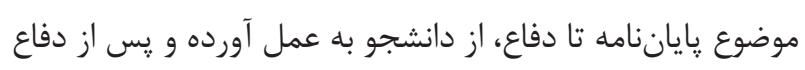

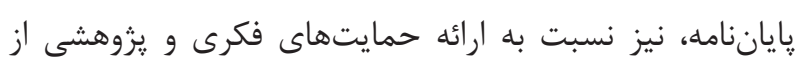
دانشآموختگان، ادامه دهند؛ و دورههاى آموزشى براى استادان راهنما و مشاور، به ويثه استادان جديد استخدام در خصوص فنون و مهارتهاى راهنمايى و هدايت پاياننامهها بر گزار شود.

\section{تشكر و قدردانى}

اين مقاله قسمتى از ياياننامه كارشناسى ارشد در رشته آموزش

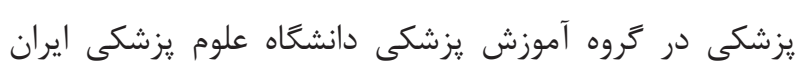
مىباشد.

\section{تضاد منافع}

بدين وسيله نويسندگًان تصريح مىنمايند كه هيجزَ كونه تضاد منافعى در خصوص يزوهش حاضر وجود ندارد.

\section{References}

1- Refahy M, Refayy E, Saabet A. The quality and how to implement it: a survey of practitioners University of Medical Sciences. Research in Medical Sciences. 2001;6(1).

2- Regulation of the Thesis of Tabriz University of Medical Sciences, (2004).

3- Fadaei Araqi GR. Analysis of Method in preparing Thesis and Dissertation in postgraduate and Doctoral Degree. Quarterly Journal of research and planning in Higher Education. 1995;1:75110.
همجنين در زَارش مر كز (GCA: Graduate Careers Australia)

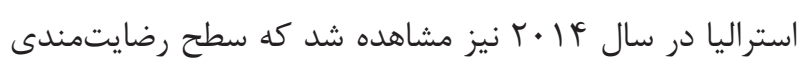
كلى دانشجويان دكترا از سريرستى پايان نامه بيشتر از دانشجويان كارشناسى ارشد بوده است. پاياننامه به معناى تأييد پايانى كار تحصيلى دانشجويان است كه است نشاندهنده فعاليتهاى منسجم اوست كه با راهنمايى و ارشاد

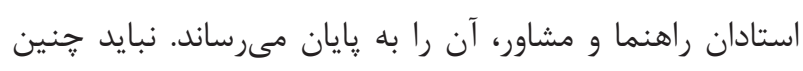
تصور شود كه پاياننامه مانند درسهاى ديخر جنبه تمرينى دارد. تدارك و نتارش يايان نامه با توجه به اينكه مدت قابل توجهى وقت

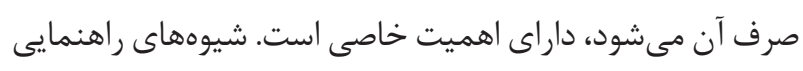
يايان نامه دانشجويان تحصيلات تكميلى، معمولاًا از خط مشىهـا و رويلهاى مندرج در آيين نامههاى مؤسسات آموزش عالى كه Fاهى مبههم و متناقض است، يِيروى مى كند. از سوى ديخر، از

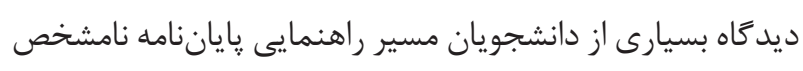
و مملو از موانع و عدم اطمينان است. اين تحقيق با هدف مقايسه رضايتمندى دانشجويان تحصيلات تكميلى و دستياران يزشكى از سريرستى قايان نامه در دانشعاه علوم يزشكى ايران انجام شد. يافتههاى تحقيق نشان داد كه

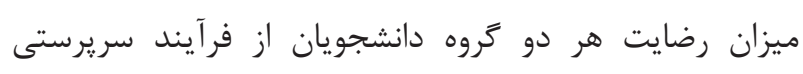
يايان نامههايشان، در حد نسبتاً مطلوب بود اما دستياران در مقايسه با دانشجويان تحصيلات تكميلى، رضايت بيشترى داشتهاند. حيطه

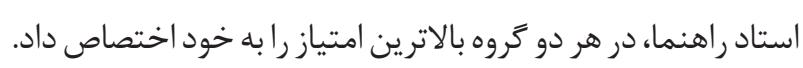
با توجه به اينكه بين حيطههاى تصويب طرح مقدماتى، ارائه شرايط و زمينههاى رشد فكرى، گسترش مهارتها و شفافسازى معيارها و اهداف با ميزان رضايتمندى در دانشجويان تحصيلات تكميلى رمينى

4- Kabra SK, Verma IC. Thesis during MD: Must or bust. Indian J pediatr. 2007;79(9):686-9.

5- Davami M, Moien L, Rafei M. Review of the principles of medical graduate theses writhing of Arak university of medical science during 1994-2000. Arak Med Uni J. 2001:23-31.

6- Khodayarian M, Mirmohammadi J, Salimi T, Araban M, Mojahed SH, Resaee M. Determining the competency dimensions of supervision professor from the nursing student viewpoints. A qualitative study. Iranian journal of Medical Education and 
Development. 2011;11(4):332-44.

7- Ginns P. Institute for teaching and learning, Level 3: University of Sydney; 2006 [Available from: http:// www.vsyd.edu.au/ research / opportunities/ supervisots/762.

8- Althubaiti A. Undergraduate Medical Research Programme: A Cross-Sectional Study of Students' Satisfactions, Perceived Challenges, and Attitudes. Glob J Health Sci. 2015;7(5):117-23.

9- Hunskaar S, Breivik J, Siebke M, Tommeras K, Figenschau K, Hansen JB. Evaluation of the medical student research programme in Norwegian medical schools. A survey of students and supervisors. BMC Medical Education. 2009;9(1):43.

10- Zeng LM, Webster BJ, editors. Assessing the research experience of postgraduate students at a Hong Kong university. the 33rd HERDSA Annual International Conference; 2010 6-9 July 2010; Melbourne, Australia.

11- Agu N, Odimegwo CO. Doctoral Dissertation Supervision: Identification and Evaluation of Models. Hindawi Publishing Corporation Education Research International.

12- Rose R, Nick SR. TLD teaching evaluation group. PREQ Report. 2007.

13- Jowett Cl. Postgraduate questionnaire for Research students 2004/5. University of Edinburgh, Senatus postgraduate studies committee. 2006.

14- Brown G, Atkins M. Effective Teaching in Higher Education. 1st Ed ed. London Methuen; 1988. 118 p.

15- Mabrouk PA, Peters K. Student perspectives on undergraduate Research Experience in chemistry and Biology. CUR Quarterly 2000;21:25-33.

16- Ismail A, Zainal Abedin N, Hassan A. Improving the development of postgraduates research and supervision. International Education Studies. 2011;4(1):78-90.

17- Ford Lioyd B. Postgraduate Research Experience survey (PRES) Birmingham: University of Birmingham; 2011 [Available from: http://internet.birmingham.ac.uk/as/studentservices / graduateschool/pgrsuport/presrep.aspx.

18- Chtris P, Andria U, Malgorzata K, Lee H. Postgraduate research experience survey: Final report 2007. United Kingdom: The
University of Leicester; 2007.

19- Haghjooy Javanmard S, Mansourian M. Factors affecting Deliberate Learning in first year students of Nursing and Midwifery school of Isfahan university of medical sciences. Iranian journal of medical education 2011;10(5):675-82.

20- Koslowsky M. A comparision of Two Attitudes, Behavior Models for predicting Attrition in Higher Education. Journal of applied behavioral science. 1993;29(1):359-66.

21- Shahshahani S, Hosseinzadeh S, Abdi K, Myrjany Aghdam A. Satisfaction of the guidance and mentoring graduate students at the University of Social Welfare and rehabilitation thesis. Iranian journal of Medical Education and Development. 2014;3(12):10319.

22- Asadollahi M, Shmas A, Rezaei M. The role of self-efficacy experience Zanjan University Graduate Master Builder. Agricultural Education Management Research Quarterly. 2015.

23- Rad afshar G, Sobhani AR, Sadeq F. Viewpoints of Medical Sciences towards the end of a process. Guilan University of Medical Sciences. 2011;19(74):86-97.

24- Behzadi H, Davarpanah M. Factors affecting the research experience Mashhad University of Medical Sciences graduate students. Journal of Education and Psychology. 2010;10(2):22750.

25- Parker C, Hamburg A, Kulej M, Harvey L. Postgraduate Research Experience survey: Higher Education Academy; 2007 [Available from: http://www.heacademy.ac.uk/assets/York/documents/ aurwork/research/survey/pres/PREs.pdf..

26- Careers G. Postgraduate Research Experience 2014. A report on the postgraduate research experience perceptions of recent higher degree research graduates. Australia: Graduate Careers; 2015.

27- Mizani M, Khabiri M, Sajadi SN. The ability of civil education graduate students and professors tips on writing quality. Quarterly Research and Planning in Higher Education. 2012;61:111-34.

28- Mooney CJ. The Dissertation is Still a Valuable Requirement, Survey Finds, but Graduate Students Says They Need Better Faculty Advising. The Chronicle of Higher Education. 1991;37:1522. 